\title{
Human Milk Feeding Enhances the Urinary Excretion of Immunologic Factors in Low Birth Weight Infants
}

\author{
RANDALL M. GOLDBLUM, RICHARD J. SCHANLER, CUTBERTO GARZA, AND \\ ARMOND S. GOLDMAN \\ Departments of Pediatrics, Human Biological Chemistry and Genetics, and Microbiology, The University of \\ Texas Medical Branch, Galveston, Texas 77550 [R.M.G., A.S.G.], and the Department of Pediatrics, Baylor \\ College of Medicine, and the U.S. Department of Agriculture Children's Nutrition Center, \\ Houston, Texas 77030 [R.J.S., C.G.]
}

\begin{abstract}
The effects of fortified human milk feedings on the urinary excretion of lactoferrin, lysozyme, secretory component, $\operatorname{IgA}$, and secretory $\operatorname{IgA}$ antibodies to Escherichia coli $\mathrm{O}$ antigens were investigated in very low birth wt infants. Infants were maintained on either a human milk or a cow's milk preparation. The amounts of each immune factor that were ingested and excreted were quantified during balance studies conducted at 2.5 and 5 wk of age. Serum levels of these immune factors were similar in both feeding groups. The urinary excretion of all factors except lysozyme was 7- to $\mathbf{1 5 0}$-fold greater in infants fed human milk than in those fed cow's milk formula. IgA was the only factor for which the amount of the factor excreted correlated with the amount ingested. Fragments as well as whole molecules of lactoferrin were found in the urine of the infants fed human milk, but the molecular sizes of the excreted proteins exceeded those normally filtered by the kidneys. Therefore, the genesis of the enhanced levels of host defense factors in the urine of infants fed human milk is not clear. Gastrointestinal absorption and subsequent renal excretion as well as enhanced production of immune factors in the infant's urinary tract are possible explanations. (Pediatr Res 25:184-188, 1989)
\end{abstract}

\section{Abbreviations}

SIgA, secretory IgA

SC, secretory component

VLBW, very low birth weight infants

FHM, fortified human milk

CMF, cow's milk formula

ELISA, enzyme-linked immunosorbent assay

The concept that human milk protects the recipient infant is supported by the demonstration of reduced infectious morbidity among breast-fed compared to artificially fed infants and by the presence of certain host defense factors in high concentrations in human milk (1-6). It has been assumed that this protection is

Received April 22, 1988; accepted October 12, 1988

Correspondence Randall M. Goldblum, M. D., Department of Pediatrics, Child Health Center, Rm. C2-31, University of Texas Medical Branch, Galveston, TX 77550 .

Supported by contracts from the National Institute of Child Health and Human Development (NO1 HD 22814; NO1 HD 62918) and grants from the National Institute of Allergy and Infectious Diseases (RO1 Al 21412-04) and Mead Johnson, Nutritional Group. mediated by the complex system of immunologic factors in the milk $(5,6)$ or by interaction of milk factors with agents produced by the infant (7). Several studies have examined the effect of human milk feeding on the concentration of immune factors in body fluids and excretions of the infant (8-24). In some studies, the fecal excretion of IgA, lactoferrin, and lysozyme was increased in infants fed human milk, a result which suggested that a portion of the ingested factors survived passage through the gastrointestinal tract (8-13). However, a maternal origin for the immune factors was not proven in those investigations. Studies of the effects of human milk feeding on immune factors in the saliva and nasal secretions of infants (14-21) have produced conflicting results, perhaps because of variable contamination of the secretions with infants' serum or maternal milk (21). The effect of human milk feeding on the infant's serum immunoglobulin concentrations also remains controversial (22-25).

To investigate the in vivo effects of feeding human milk, we developed a human milk preparation for experimental use in premature infants. It was previously ascertained that this preparation met reasonable microbiologic standards (26), that the concentrations of many of the immunologic factors in the preparation were maintained after brief high temperature treatment (26), and that its use resulted in growth rates similar to those observed during intrauterine life (27). We have also studied its effects on the fecal excretion of selected immunologic factors in VLBW infants (28). The fecal excretion of human lactoferrin, lysozyme, SIgA, and SIgA antibodies to a pool of Escherichia coli somatic $(\mathrm{O})$ antigens was greater in infants fed fortified human milk than in those fed a cow's milk formula. No correlation between the ingestion and fecal excretion of individual factors was noted except for SIgA antibodies to $E$. coli $\mathrm{O}$ antigens. Although no correlations were noted between the ingested amounts of lactoferrin, lysozyme, and SIgA, the excreted amounts of these factors were positively correlated with each other. That observation suggested that unidentified factors in milk may enhance the coordinated production of certain mucosal immune factors by the infant (28).

To investigate further the possible effects of this human milk preparation on the mucosal immunity of premature infants, we measured the excretion of immunologic factors in the urine of these VLBW infants $(27,28)$. Urine was chosen because that external secretion is produced in part by epithelial cells that are not in direct contact with ingested milk, and because it can be collected continuously during test balance periods. The design permitted us to compare the amounts of immunologic factors in the ingested milk with the concentrations of these factors in peripheral blood and the amounts excreted in stool (28) and urine. 


\section{MATERIALS AND METHODS}

Study design. The study was approved by the institutional review boards of both participating institutions. Two groups of VLBW infants were studied concurrently. One group received only FHM prepared daily by adding heat-treated, lyophilized, mature donor milk to fresh maternal milk (26-28). The other group was fed a CMF designed for VLBW infants. The study groups were similar with respect to gestational age $(28-30 \mathrm{wk})$, age at time of balance studies ( $2.5 \mathrm{wk}$ for the first period; $5 \mathrm{wk}$ for the second period), wt gain, gastrointestinal transit time, total fecal output $(27,28)$, and creatinine clearance. Each group received either FHM or CMF exclusively from the time enteral feedings were begun. During the first balance study period, either the FHM or a CMF (Similac PM 60/40, Ross Laboratories, Columbus, $\mathrm{OH}$ ) was fed by continuous nasogastric infusion. During the second period, the infants were fed either the FHM or a CMF formula (Similac 24, Ross Laboratories) by intermittent nasogastric administration. Each subject received the prescribed feedings for at least $1 \mathrm{wk}$ before the balance study. The total vol, caloric, and nitrogen intakes were similar to the two experimental groups (27). Additional details of the feeding protocol have been described $(27,28)$.

During the 96-h balance periods, the infants were placed on a mesh hammock overlying a stainless steel tray arranged for continuous collection of urine. The urine and deionized water rinse drained directly into containers maintained on ice. Unless spills or contamination occurred, individual 12-h urine collections were pooled into four 24-h collections. Human lactoferrin, lysozyme, IgA, and SIgA antibodies to $E$. coli were measured in aliquots of milk and urine, and total $\mathrm{SC}$ was measured in urine. At the end of each 96-h collection, a serum sample was obtained to quantify immunoglobulins, lactoferrin, and lysozyme.

Immunologic methods. Total IgA and SIgA in milk and total IgA in urine were quantified by immunofluorescence assays using as detectors antihuman $\alpha$-chain (Bio-Rad Laboratories, Chemical Division, Richmond, CA) and antihuman SC antibodies, respectively (29). Lactoferrin and lysozyme in milk were measured by electroimmunodiffusion using monospecific antisera (Calbiochem-Behring Corp., La Jolla, CA) (29). Lactoferrin and lysozyme in urine and serum were quantified by ELISA (28).

Total SC (free SC, SIgA, and SIgM) in urine was measured by a competitive ELISA method using a horseradish peroxidase conjugate of a MAb (3F7) which reacts with similar avidity to fluid phase free SC and SIgA (30). Conjugated antibody $(0.1 \mathrm{ml})$ diluted 1:4000 in PBS containing Tween-20 (Sigma Chemical Co., St. Louis, MO) and protease inhibitors was mixed with 0.3 $\mathrm{ml}$ of urine or purified SIgA standards. Polyethylene glycol 6000 was added to achieve a final concentration of $8.5 \%$ (wt/vol), and the mixture was incubated at $4^{\circ} \mathrm{C}$ overnight. After centrifugation at $400 \times g$ for $20 \mathrm{~min}$, the supernatant was transferred to microtiter plates coated with purified SIgA and incubated for 2 $\mathrm{h}$ on ice. Next, the plates were washed, assayed for enzyme activity, and the results expressed as logit of the percentage of antibody conjugate bound. Values for each sample were compared with a standard curve produced from SIgA standards. The sensitivity of the assay was $\sim 30 \mathrm{ng} / \mathrm{ml}$, and the response was linear to $4 \mu \mathrm{g} / \mathrm{ml}$.

Secretory IgA antibodies to a pool of $E$. coli $\mathrm{O}$ antigens were quantified by ELISA using antisera to human IgA and SC conjugated to horseradish peroxidase as detectors (29). Serum levels of $\operatorname{IgG}, \operatorname{IgA}$, and $\operatorname{IgM}$ were quantified by rate nephelometry (31).

The molecular sizes of lactoferrin and SC in urine were examined by Western blotting (32). Urine samples concentrated 20- to 30-fold by Minicon 10 (Amicon Corp., Danvers, MA) were mixed with equal amounts of the SDS sample buffer and separated by electrophoresis in $7.5 \%$ acrylamide gel. The proteins were then transferred electrophoretically from the gel to nitrocellulose sheets. The sheets were blocked with $3 \%$ gelatin and then incubated with rabbit antisera to either human lactoferrin, IgA, or SC (Dako Corporation, Santa Barbara, CA), washed, and then incubated with goat antisera to rabbit $\mathrm{IgG}$ conjugated to horseradish peroxidase (Bio-Rad). After a further wash, the enzyme bound to the sheets was localized by applying chloronaphthol and hydrogen peroxide in methyl alcohol.

The immunologic assays used in this study did not detect any antigens in the cow's milk preparations fed to the VLBW infants.

Data presentation and analysis. The data for immune factors in the milk and urine were not distributed normally. Natural logarithmic transformations of the data were therefore performed for statistical analyses, including repeated measures analysis of variance, Student's $t$ test, and multiple linear regression (33). Since multiple comparisons were performed, $p$ values $<0.01$ were considered significant. Because there were no differences between results obtained in the first and second balance study periods for either feeding group, the data from both balance periods were combined for presentation. Results are presented as medians, 25 th percentiles, and 75 th percentiles.

\section{RESULTS}

Quantitative urinary excretion of immunologic factors. The median urinary excretion of lactoferrin, IgA, and total SC in infants fed FHM was increased 7- to 150-fold over that found in CMF-fed infants (Table 1). The quantities of urinary lysozyme were similar in the two groups $(p>0.5)$. Secretory IgA antibodies to $E$. coli $\mathrm{O}$ antigens were found in the urine of $21 \%$ of the infants fed FHM but were not detected in the urine of any infants fed CMF.

Serum concentrations of immunologic factors. There were no differences between the two feeding groups in the concentrations of serum immunoglobulins (including SIgA), lactoferrin, or lysozyme (Table 2).

Correlation analysis. Significant positive correlations were found in the FHM-fed group between urinary lactoferrin, SC, and $\operatorname{IgA}$, and between $\operatorname{IgA}$ in urine and milk. The urinary excretion of these patients was also compared to their fecal excretion in the same infants as reported previously (28). A correlation was found between urinary SIgA antibodies to E. coli and fecal lactoferrin (Table 3). No other significant correlations were found between quantifications of the ingestion, serum concentration, urinary excretion, or fecal excretion of any of the factors.

Table 1. The intake and urinary excretion of immunologic factors by $V L B W$ infants during balance studies

\begin{tabular}{|c|c|c|}
\hline \multirow[b]{2}{*}{$\begin{array}{l}\text { Immune factors } \\
(\mathrm{mg} / \mathrm{kg} / 96 \mathrm{~h})\end{array}$} & \multicolumn{2}{|c|}{ Experimental groups* } \\
\hline & $\begin{array}{c}\text { FHM } \\
(n=33) \dagger\end{array}$ & $\begin{array}{c}\text { CMF } \\
(n=20)\end{array}$ \\
\hline \multicolumn{3}{|l|}{ Lactoferrin } \\
\hline Intake & $1234(794 ; 1504) \ddagger$ & 0 \\
\hline Urinary Excretion & $1.5(0.5 ; 7.1)$ & $0.01(0.001 ; 0.02)$ \\
\hline \multicolumn{3}{|l|}{ Lysozyme } \\
\hline Intake & $80(50 ; 140)$ & 0 \\
\hline Urinary Excretion & $0.08(0.03 ; 0.14)$ & $0.05(0.03 ; 0.09)$ \\
\hline \multicolumn{3}{|l|}{$\operatorname{IgA}$} \\
\hline Intake & $654(471 ; 918)$ & 0 \\
\hline Urinary Excretion & $3.1(0.7 ; 12.5)$ & $0.06(0 ; 0.13)$ \\
\hline \multicolumn{3}{|l|}{$\mathrm{SC}$} \\
\hline Intake & ND & ND§ \\
\hline Urinary Excretion & $1.39(0.61 ; 7.13)$ & $0.21(0.15 ; 0.28)$ \\
\hline
\end{tabular}
0.32 )

${ }^{*} p<0.001$ for all comparisons between groups except lysozyme $(p<$

$\dagger$ Number of subjects in combined balance studies.

$\ddagger$ Data expressed as median (25th percentile; 75 th percentile)

$\S$ Not determined. 
Table 2. Serum concentrations of immunologic factors in $V L B W$ infants fed FHM or CMF*

\begin{tabular}{ccc}
\multirow{2}{*}{$\begin{array}{c}\text { Immune } \\
\text { factors }\end{array}$} & \multicolumn{2}{c}{ Experimental groups } \\
\cline { 2 - 3 } IgG $\dagger$ & FHM & CMF \\
IgM $\dagger$ & $267 \pm 129(22)$ & $251 \pm 105(11)$ \\
IgA $\dagger$ & $37 \pm 18(24)$ & $36 \pm 4(11)$ \\
SlgA $\dagger$ & $2.7 \pm 2.3(29)$ & $4.4 \pm 7.4(12)$ \\
Lactoferrin $\ddagger$ & $0.8 \pm 0.5(27)$ & $0.7 \pm 0.4(9)$ \\
Lysozyme $\ddagger$ & $0.9 \pm 0.5(29)$ & $0.8 \pm 0.8(12)$ \\
\hline
\end{tabular}

*All data are presented as the mean \pm SD (number of subjects). Differences between feeding groups were not statistically significant.

$\dagger$ Data are expressed as $\mathrm{mg} / \mathrm{dl}$

$\ddagger$ Data are expressed as $\mu \mathrm{g} / \mathrm{ml}$.

Table 3. Significant correlations between the amounts of immunologic factors ingested and excreted and between different factors excreted in the urine of $V L B W$ infants fed FHM

\begin{tabular}{lcl}
\multicolumn{1}{c}{ Comparisons } & $r$ values & $p$ values \\
\hline Urine lactoferrin vs. urine IgA & 0.87 & $<0.001$ \\
Urine lactoferrin vs. urine SC & 0.66 & $<0.001$ \\
Urine IgA vs. urine SC & 0.58 & $<0.001$ \\
Urine IgA vs. milk IgA & 0.74 & $<0.001$ \\
Urine SIgA antibodies to E. coli vs. & 0.94 & $<0.01$ \\
stool lactoferrin & & \\
\hline
\end{tabular}

Molecular forms of immunologic factors in urine. Lactoferrin, monomeric IgA, free SC, and SIgA were detected by Western blotting in the urine of FHM-fed infants, but not in urine of CMF-fed infants (Fig. 1). All of the urine samples which demonstrated lactoferrin in this assay had bands which comigrated with the lactoferrin standard (70-80 kD). Lower mol wt forms of lactoferrin that are not present in milk were also detected consistently in these samples. The migration of these principal moieties indicated that their mol wt were approximately $55 \%$, $49 \%, 43 \%$, and $39 \%$ of the mol wt of native lactoferrin.

Blots stained with antisera to human SC demonstrated bands which comigrated with standards for free SC and SC covalently linked to polymeric immunoglobulin (SlgA; data not shown). Any SC which was noncovalently associated with immunoglobulins would have been dissociated by the SDS and appeared on the blots as free SC.

\section{DISCUSSION}

Our study demonstrates that the urinary excretion of immunoreactive human lactoferrin, $\mathrm{IgA}, \mathrm{SC}$, and $\mathrm{SIgA}$ antibodies to $E$. coli $\mathrm{O}$ antigens was much greater in VLBW infants fed FHM than in those fed CMF. We considered whether methodologic problems were responsible for those findings. We found no evidence for spillage of FHM or stool into the urine collection, as there were no correlations between the amounts of each factor in milk (28) and urine. To test further whether the urine was contaminated by human milk, we assayed aliquots for $\alpha$-lactalbumin, a protein unique to human milk and present there in high $(\mathrm{mg} / \mathrm{ml})$ concentrations. Less than half the urine samples from the FHM-fed infants contained detectable $\alpha$-lactalbumin ( $>6 \mathrm{ng} / \mathrm{ml}$; data not shown). When the protein was detected, the amount did not correlate with the quantities of the immunologic factors in the urine. If $\alpha$-lactalbumin is used as a marker for contamination, the maximum extent of contamination of urine samples by milk would be estimated to be less than $1 \mathrm{ppm}$. This level of contamination could not explain the increased urinary excretion of immune factors.

\section{H H L H C L}

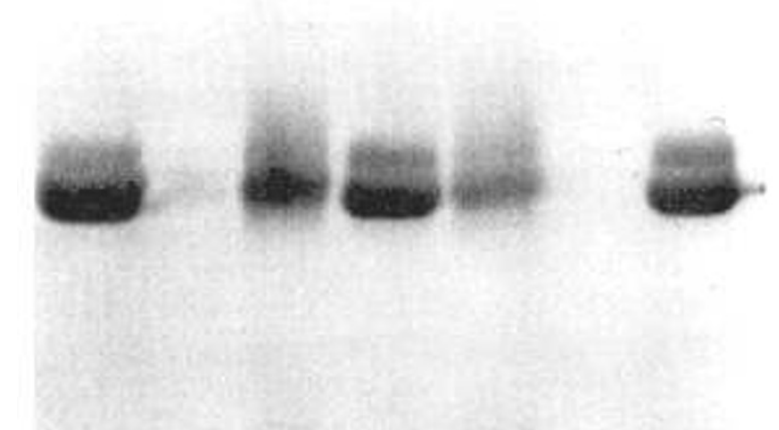

Fig. 1. Western blot analysis of urinary lactoferrin. Concentrated urine from infants fed FHM are shown in lanes marked $H$. The lanes marked $L$ contained lactoferrin purified from human colostrum. The lane marked $C$ was typical of the analyses on concentrated urine from infants fed CMF.

Were the increased levels of immunologic factors in the urine of infants fed FHM derived from ingested milk proteins? This hypothesis was supported by the abundance of these factors in the FHM and their relative resistance to proteolysis by enzymes in the alimentary tract (5). We therefore examined the size of the SC and lactoferrin molecules in the urine from FHM-fed infants. The SC in the urine was present in the free form and bound to IgA dimers. The molecular forms of urinary $\operatorname{IgA}$ were not analyzed directly, but the presence of high mol wt SC on blots and the demonstration of specific SIgA antibodies to $E$. coli indicate that some intact SIgA was present in the urine of infants fed FHM.

Although lactoferrin in the milk was only detected as whole molecules, the urine contained intact lactoferrin and fragments similar in size to those found in the stools of these same FHMfed infants (data not shown) or produced in vitro by partial tryptic digestion (34). Since the antilactoferrin antiserum used in the ELISA and Western blotting assays reacted with lactoferrin fragments, some of the increase in the lactoferrin measured in urine of HMF-fed infants was likely due to these fragments. Further, the similarity in size of the lactoferrin fragments in the stool and urine suggests that the VLBW infants fed FHM may absorb lactoferrin fragments and excrete them in the urine.

Not all of the differences in the concentration of the immune factors in the urine can be explained by intestinal absorption of immunoreactive fragments, however. Intact lactoferrin, free SC, and SIgA were demonstrated by Western blotting in the urine of FHM-fed but not CMF-fed infants. Serum concentrations of lactoferrin were not increased in infants fed FHM, as one might expect if lactoferrin were absorbed from the gastrointestinal tract. Finally, the sizes of the immune factors in urine, including most of the lactoferrin fragments, were larger than those normally filtered by glomeruli $(35,36)$.

We also questioned whether the enhanced excretion of im- 
munologic proteins might be mediated by specific receptors in the intestinal and urinary tracts. Receptors for human lactoferrin have been demonstrated on brush border preparations from rabbit and human intestinal epithelial cells $(37,38)$, but they are not thought to mediate absorption of lactoferrin. Binding to these receptors may, however, enhance the absorption of lactoferrin fragments by less specific mechanisms. Secretory component, an epithelial receptor for polymeric $\operatorname{IgA}$, is also present on enterocytes (39). However, the basolateral localization of SC on enterocytes and lack of SC binding of SIgA, the principal form of $\mathrm{IgA}$ in human milk, including milk from mothers of premature infants (40), argue against SC-mediated intestinal absorption of IgA. Similarly, it seems unlikely that the increased concentration of free SC, demonstrated in the urine of the FHM-fed infants by Western blotting could be attributed to absorption and transport of milk SC, as SC is synthesized as an integral membrane protein and released at the luminal surface of epithelial cells $(41,42)$.

An alternate explanation for these results is that feeding human milk enhances the synthesis of immune factors in the infant's urinary tract. Given the lack of correlation between the amounts of different immune factors in milk (28), the presence of a correlation between the urinary excretion of lactoferrin, total SC, and $\operatorname{IgA}$ in infants fed FHM is consistent with coordinated production of urinary immune factors. Induction of synthesis by the infant is a particularly attractive explanation for the presence of intact lactoferrin and free SC in the urine of FHM-fed low birth wt infants.

Recently, Prentice (43) has reported that the breast feeding increases the urinary excretion of IgA 3-fold in 6-and 12-wk-old term infants (43). The urinary excretion of lactoferrin was not significantly increased in that study. Differences in specimen collection methods make it difficult to compare the quantity of urinary $\operatorname{IgA}$ and lactoferrin excretion reported (43) to the present study. However, her results indicate that enhancement of urinary excretion of immunologic components by human milk feeding is not restricted to premature infants.

The biologic significance as well as the mechanistic basis of the increased concentration of immune factors in the urine of VLBW infants fed FHM is unclear. Although a direct role for local immune factors in protecting the urinary tract against infection has not been demonstrated, girls with recurrent urinary tract infections have diminished levels of SIgA in their urine when they are not actively infected (44), and affected women have diminished urinary IgA between and during active infections (45). Further studies will help to ascertain whether breastfeeding protects against urinary tract infection and whether human milk feeding enhances production or secretion of host defense factors at other mucosal sites.

Acknowledgments. The authors thank K. H. Palkowetz for her technical assistance and S. C. Kovacevich and P. A. Muldrow for their secretarial assistance in preparing this manuscript.

\section{REFERENCES}

1. Cunningham AS 1981 Breast-feeding and morbidity in industrialized countries: an update. In: Jelliffe DB, Jelliffe EFP (eds) Advances in International Maternal and Child Health. Oxford University Press, New York, pp 128168

2. Sauls HS 1979 Potential effect of demographic variables and other variables in studies comparing morbidity of breast-fed and bottle-fed infants. Pediatrics 64:523-527

3. Habicht J-P, DaVanze J, Butz WP 1986 Does breastfeeding really save lives, or are apparent benefits due to biases? Am J Epidemiol 123:279-290

4. Kramer MS 1987 Breast feeding and child health: methodologic issues in epidemiologic research. In: Goldman AS, Atkinson AS, Hanson LA (eds) Human Lactation III. The Effects of Human Milk Upon the Recipient Infant. Plenum Press. New York, pp 339-360

5. Goldman AS, Goldblum RM 1985 Protective properties of human milk. In: Walker WA and Watkins JB (eds) Nutrition in Pediatrics-Basic Sciences and Clinical Application. Little, Brown, and Company, Boston, pp 819-828

6. Goldman AS, Ham Pong AJ, Goldblum RM 1985 Host defenses: development and maternal contributions. In: Barness LA (ed) Advances in Pediatrics. Yearbook Medical Publishers, Chicago, pp 32:71-100
7. Gothefors L, Marklund S 1975 Lactoperoxidase activity in human milk and in saliva of newborn infants. Infect Immun 11:1210-1215

8. Haneberg B, Funne P 1974 Lysozymes in feces from infants and children. Acta Paediatr Scand 63:588-594

9. Haneberg B 1974 Immunoglobulins in feces from infants fed human or bovine milk. Scand J Immunol 3:191-197

10. Ogra SS, Weintraub D, Ogra PL 1977 Immunologic aspects of human colostrum and milk III: fate and absorption of cellular and soluble components in the gastrointestinal tract of the newborn. J Immunol 119:245-248

11. Spik G, Brunet B, Mazurier-Dehaine C, Fontaine G, Montreuil J 1982 Characterization and properties of the human and bovine lactotransferrins extracted from the faeces of newborn infants. Acta Paediatr Scand 71:979-985

12. Prentice A, Ewing G, Roberts SB, Lucas A. MacCarthy A, Jarjou LMA Whitehead RG 1987 The nutritional role of breast-milk IgA and lactoferrin. Acta Paediatr Scand 76:592-598

13. Davidson LA, Lonnerdal B 1987 Persistence of human milk proteins in the breast-fed infant. Acta Paediatr Scand 76:733-740

14. Gleeson M, Cripps AW, Clancey RL, Husband AJ, Hensley MJ, Leeder SR 1982 Ontogeny of the secretory immune system in man. Aust NZ J Med 12:255-258

15. Roberts SA, Freed DLJ 1977 Neonatal IgA secretion enhanced by breast feeding. Lancet 2:1131

16. Gross SJ, Buckley RH 1980 IgA in saliva of breast-fed and bottle-fed infants. Lancet 2:543

17. Taylor CE, Toms GL 1984 Immunoglobulin concentrations in nasopharyngeal secretions. Arch Dis Child 59:48-53

18. Ostergaard PAA 1985 Serum and saliva Ig-levels in infants of non-atopic mothers fed breast milk or cow's milk-based formulas. Acta Paediatr Scand 74:555-559

19. Gleeson M, Cripps AW, Clancy RL, Hensley MJ, Dobson AJ, Firman DW 1986 Breast feeding conditions a differential developmental pattern of mucosal immunity. Clin Exp Immunol 66:216-222

20. Stephens S 1986 Development of secretory immunity in breast fed and bottle fed infants. Arch Dis Child 61:263-269

21. Aldred MJ, Vaughn AG, Yuill SJ, Wade WG, Walker DM 1986 Persistence of IgA in neonatal saliva following breast feeding. Early Hum Dev 14:273276

22. Saarinen UM, Pelkonen P, Siimes MA 1979 Serum immunoglobulin A in healthy infants: an accelerated postnatal increase in formula-fed compared to breast-fed infants. J Pediatr 95:410-412

23. Savilahti F, Jarvenpaa AL, Raiha NCR 1983 Serum immunoglobulins in preterm infants: comparison of human milk and formula feeding. Pediatrics 72:312-316

24. Stephens S, Kennedy CR, Lakhani PK, Brenner MK 1984 In-vivo immune responses of breast- and bottle-fed infants to tetanus toxoid antigen and to normal gut flora. Acta Paediatr Scand 73:426-432

25. Ballow M, Cates KL, Rowe JC, Goetz C, Desbonnet C 1986 Development of the immune system in very low birth weight (less than $1500 \mathrm{~g}$ ) premature infants: concentrations of plasma immunoglobulins and patterns of infections. Pediatr Res 9:899-904

26. Goldblum RM, Dill CW, Albrecht TB, Alford ES, Garza C, Goldman AS 1984 Rapid high-temperature treatment of human milk. J Pediatr 104:380-385

27. Schanler RJ, Garza C, Nichols BL 1985 Fortified mother's milk for very low birthweight infants: results of growth and nutrient balance studies. J Pediatr 107:437-448

28. Schanler RJ, Goldblum RM, Garza C, Goldman AS 1986 Enhanced fecal excretion of selected immune factors in very low birth weight infants fed fortified human milk. Pediatr Res 20:711-715

29. Goldblum RM, Garza C, Johnson CA, Harrist R, Nichols BL, Goldman AS 1981 Human milk banking I: effects of container upon immunologic factors in mature milk. Nutr Res 1:449-459

30. Woodard CS, Splawski JB, Goldblum RM, Denney RM 1984 Monoclonal antibodies to human free secretory component, secretory IgA, and membrane secretory component. J Immunol 133:2116-2125

31. Ritchie RF 1975 Automated immunoprecipitation analysis of serum proteins. In: Putnam FW (ed) The Plasma Proteins. Structure, Function, and Genetic Control. Academic Press, New York, pp 375-425

32. Symington J 1983 Electrophoretic transfer of proteins from two dimensional gels to sheets and their detection. In: Celis JE, Bravo R (eds) Two Dimensional Gel Electrophoresis of Proteins: Methods and Applications. Academic Press, New York, pp 3-36

33. Winer BJ 1962 Statistical Principles in Experimental Design, 2nd ed. McGrawHill, New York

34. Brines RD, Brock JH 1983 The effect of trypsin and chymotrypsin on the in vitro antimicrobial and iron-binding properties of lactoferrin in human milk and bovine colostrum. Biochim Biophys Acta 759:229-235

35. Brenner BM, Dworkin LD, Ichikawa I 1986 Glomerular ultrafiltration. In: Brenner BM, Rector Jr FC (eds) The Kidney, vol 1. W.B. Saunders Company, Philadelphia, 124-144

36. Dworkin LD, Brenner RM 1985 Biophysical basis of glomerular filtration. In: Seldin DW, Giebish G (eds) The Kidney: Physiological Pathophysiology. Raven Press, New York, pp 397-426

37. Cox TM, Mazurier J, Spik G, Montreuil J, Peters TJ 1979 Iron binding proteins and influx of iron across the duodenal brush border: evidence for specific lactotransferrin receptors in the human intestinc. Biochim Biophys Acta 588:120-128

38. Mazurier J, Montreuil J, Spik G 1985 Visualization of lactotransferrin brush border receptors by ligand-blotting. Biochim Biophys Acta 821:453-460 
39. Brandtzaeg P 1978 Polymeric IgA is complexed with secretory component (SC) on the surface of human intestinal epithelial cells. Scand J Immunol 8:3952

40. Goldman AS, Garza C, Nichols B, Johnson CA, Smith E, Goldblum RM 1982 The effects of prematurity upon the immunologic system in human milk. J Pediatr 101:901-905

41. Mostov KE, Blobel G 1983 A transmembrane precursor of secretory component: the receptor for transcellular transport of polymeric immunoglobulins. J Biol Chem 257:11816-11821
42. Solari R, Kraehenbuhl JP 1984 Biosynthesis of the IgA antibody receptor: a model for the transepithelial sorting of a membrane glycoprotein. Cell 36:6171

43. Prentice A 1987 Breast feeding increases concentrations of IgA in infants' urine. Arch Dis Child 62:792-795

44. Fliedner M, Mehls O, Rauterberg EW, Ritz E 1986 Urinary sIgA in children with urinary tract infection. J Pediatr 109:416-421

45. Riedasch G, Heck P, Rauterberg E, Ritz E 1983 Does low urinary SIgA predispose to urinary tract infection? Kidney Int 23:759-763 